\title{
PETROLEUM REVENUE MANAGEMENT IN GHANA: THE EPOCH OF HIGH EXPECTATION IN PERSPECTIVE
}

\author{
Kow Kwegya Amissah Abraham*
}

\begin{abstract}
The avoidance of resource curse is, in part, dependent on the management and administration of realized revenue from the exploration of its natural resource. This article evaluates the existing fiscal regime and the regulatory frameworks that Ghana established to manage its petroleum revenue from 2010 to 2013. The restrictive period accounts for the era where Ghanaians showed high expectations of increased benefits from oil. In this vein, the article analyses the preparedness reflected in the policy framework to manage accrued revenue and, by extension, the expectation of citizens on improved living conditions. This article established that existing mechanisms, legislation, and checks and balance procedures to manage petroleum revenues are not the final steps at ensuring sustainable development. Two crucial factors play a decisive role in this regard. First is the extent to which accrued revenue is expended in critical areas of the economy for accelerated growth. Second is the commitment to, and establishment of, strong public institutions to enforce the relevant regulations.
\end{abstract}

Keywords: Fiscal Regime, Transparency, Tax, Petroleum Revenue.

DOI: https://dx.doi.org/10.4314/jsdlp.v10i1.2

\section{INTRODUCTION}

Natural resources, such as crude oil, uranium, gold, natural gas, bauxite, and so on, are vital and strategic commodities with sustainable sources of income for countries that have them. Africa has been considered one of the leading continents with large natural resource deposits; be

* BA, MPhil (Ghana), MPP (Germany), Lecturer, University of Cape Coast, Cape Coast, Ghana, and Executive Director, Centre for Policy Research and Training. kow.abraham@ucc.edu.gh. 
it metallic, extractive and so on. Oil exploration statistics as at 2010 indicated that Africa produced 13 per cent of the global crude oil out of which sub-Saharan Africa's production was 7.25 per cent. ${ }^{1}$

Historically, Africa started oil production and export in 1908. The first oil exploration is believed to have taken place in Nigeria by a firm of German origin called Nigerian Bitumen Corporation, ${ }^{2}$ after which period oil was discovered in commercial quantities, especially, from the 1950s. Currently, there are 38 countries out of the 53 countries in Africa that export oil in commercial quantities. ${ }^{3}$ Without any reference to special cases in the selection, some of these countries are Gabon, Cameroon, Angola, Nigeria, Sudan, Chad, Ghana, South Sudan, Libya, Algeria, Equatorial Guinea, and so on. Nigeria, in this case, remains the largest producer of oil in Africa and the fourth largest producer in the world. ${ }^{4}$

The large oil reserves and export of crude oil have placed many African countries in a vantage position to radically improve the living conditions of their citizens. This is because oil is a strategic resource whose value also increases with the rate of development and technological advancement. Indeed, the indispensability of energy to social and economic development makes oil a very enviable resource. This is because two-thirds of the global energy supply derives from oil and gas. ${ }^{5}$ It, therefore, explains why the volatility of oil prices has an enormous effect on all economies, both developed and developing. With increasing demand for oil by developed nations and emerging economies like India, Brazil and China, it is expected that global energy demand will rise to 57 per cent by $2025 .^{6}$ This puts African oil exporting

1 Baumüller Heike, Elizabeth Donnelly, Alex Vines, and Markus Weimer. The Effects of Oil Companies' Activities on the Environment, Health and Development in Sub-Saharan Africa (Policy Department, Directorate-General for External Policies of the European Union 2011).

2 Anne Boschini, Jan Pettersson, and Jesper Roine. "Resource Curse or Not: A Question of Appropriability" (2007) 109 Scandinavian Journal of Economics, pp. 593-617.

3 African Development Bank, Oil and Gas in Africa (Oxford: Oxford University Press, 2009). See also Damilola Olawuyi, Extractives Industry Law in Africa (Springer, 2018), pp. 1-20.

4 Olawuyi, ibid.

5 Maureen MacNeill (ed), Annual Report 2012, OPEC (Vienna, 2013).

6 J Clemente, “OPEC REPORT-OPEC's upstream investments: Cooperation between producers and consumers is key" (Organization of Petroleum Exporting Countries: World Oil Outlook, 2012), p. 109. 
countries at an advantage as far as income generation for sustainable development is concerned. For a long time, the European Union and the United States constituted the biggest clients in Africa. China has recently joined the league not just as a potential big client interested in the purchase but also the production of oil in Africa. Indeed, more oil discoveries continue to be made in Africa; hence the continent's oil reserves have experienced steady growth yearly.

Consequently, therefore, petroleum revenue accounts for a greater share of the total income earnings of oil exporting countries. Indeed, it is one of the most dependable sources of income for such economies. This places much responsibility on the governments of these economies to put the revenues generated from oil into judicious use to promote development. Many successful oil economies have found a need to designate accrued revenues into special funds from which they finance development projects. These specially created funds, called Sovereign Wealth Funds, are a special investment set up by a government for the macroeconomic purposes of the country and also for investment strategies in the exporting economy or a savings accumulated by the government over a long period of years as a result of prudence in spending and good economic management. ${ }^{7}$ Thus, in practice, oil economies establish such funds for economic stability and developmental projects. Oil-rich countries, such as Norway, Saudi Arabia, United Arab Emirates, etc, all have a kind of sovereign wealth fund managed under different names. ${ }^{8}$

The production of oil undoubtedly leads to great expectations of a faster growth rate, higher development indices and better living conditions. Governments, therefore, have a duty to achieve these goals through effective husbandry of the oil economy. Confronted with this same test, Ghana has continued to face key challenges in the managing its petroleum rents. Critical to averting the resource curse syndrome is the commitment of its governments to putting in place policies and programmes that would reflect the huge revenues being realized from the sale of oil. Equally essential are the various fiscal and monetary policies as well as management frameworks to guide government spending. There is also the prioritizing of the most critical sectors to

7 Andrew Rozanov, "Who Holds the Wealth of Nations." In Central Banking Journal (2005) 4. 4-12.

8 Francis Ayensu, "Managing Ghana's Oil Revenue: Ghana Petroleum Funds (GPFs)." In (2013) 2 Asian Journal of Humanities and Social Sciences 1. 
which oil revenue should be allocated. Regarding exploration activities, many private companies have collaborated with the government since oil exploration began in Ghana. As of 2014, about 34 transnational companies are known to have engaged in oil exploration in Ghana.

The focus of this article is to examine the general fiscal regime of Ghana and how it impacted on the management of accrued petroleum revenue between 2010 and 2014. This is necessitated by the growing feeling of unconcern and pessimism nine years after the commercialization of oil. With oil, people expected their living conditions to improve dramatically. This high expectation permeated all circles, including the masses, the government and even the international community. To meet this expectation, people hoped for better regulatory and management frameworks to guide spending from the oil proceeds. Furthermore, this article aims to ascertain the preparedness of Ghana to commercialize its oil resource to avoid the resource curse syndrome. Experience shows that the most trumpeted reason for resource curse is poor management of petroleum revenue.

This article is divided into five sections. Section 1 is this introduction, which gives a general overview of Ghana's exploration activities. Section 2 analyses the economic situation in Ghana with reference to the macroeconomic indicators up to 2014. The article, however, refers to the prevailing circumstance in 2018 and 2019 with a view to better understand the changing trends of the economy. The motivation is to know the state of the Ghanaian economy prior to and after the commercialization of oil. Section 3 is an exposition on the petroleum revenue and fiscal framework of Ghana. It further looks at the amount Ghana accrued in its petroleum operations as revenue within the period under study. This is to know how the revenue was spent and also the guiding frameworks for the expenditure. Section 4 juxtaposes the prevailing state of the economy in previous periods with the accrued revenue, as well as how it was spent. The aim is to make policy recommendation based on the extent to which government has been prudent in managing the petroleum revenue. The final section, section 5 , is the conclusion.

\section{BRIEF MACROECONOMIC OUTLOOK OF GHANA}

The discovery of Ghana's rich natural resources dates back to pre-colonial times. The country was named "Gold Coast" by European migrants because of the large deposits of gold that were discovered when they 
first arrived on the shores of Ghana. By the early 19th century, the British colonialists had started exporting various minerals, such as gold, diamond, manganese, etc. back home. ${ }^{9}$ This, according some scholars, was why the railway system was built in Ghana - to enable easy transportation of natural resources from the hinterland to the coast for export. As at 2019, Ghana ranks second in the world export of cocoa and is the second largest exporter of gold in Africa. There is the export of bauxite, manganese, diamond, and now oil. In this vein, natural resources contribute a great deal to the GDP per capita in Ghana. With the discovery of oil, Ghana's economy was expected to rise even further. There is a forecast of US\$20 billion in revenue from oil between 2012 and 2030. ${ }^{10}$

As far as metallic natural resources are concerned, royalties paid to government ranges from 3-6 per cent. It is important to note that although Ghana is seen to have managed its mineral resources well enough to escape the resource curse, yet, as far as metallic resources are concerned, the country actually receives less than it deserves. This can be seen in the mining agreements, concessions and royalties on returns compared to what mining companies or transnational companies gain besides the detrimental effect of their activities on the environment and the inhabitants of the mining areas. There are other problems: weak legislation to oversee the mining sector activities, a delink between the royalties received and improvement of the living conditions of the people, especially those in the mining communities; weak institutions to ensure that companies keep to their social responsibility; and the non-existence of a regulatory body to check illegal mining, which is now dominated by nationals from Asia. This situation necessitates further scrutiny and assessment of how Ghana has managed its oil exploration and production so far. Thus, this work places emphasis on petroleum revenue and how it was managed within a specific period.

The 2010 population and housing census pegged Ghana's population at 24 million with the projection that it would reach 27 million by

9 D. Amenumey, Ghana: A Concise History from Pre-Colonial Times to the 20th Century (Accra: Woeli Publishing Services, 2008).

10 International Monetary Fund (IMF). (2012). Publications. www.imf.org: http:/ /www.imf.org/external/pubs/ft/reo/2012/afr/eng/sreo0412.pdf. Accessed on 3 April 2019. 
2014. ${ }^{11}$ As of 2019, the population of Ghana has risen to approximately 30 million. Ghana's pre-colonial economy was largely agrarian. This is evident in the assertion that the country's land is 65 per cent agrarian and has a GDP of US\$ 47.93 billion. ${ }^{12}$ Since 2007, when oil was discovered in commercial quantities in Ghana, and up until 2011, the country experienced a steady growth in all sectors of the economy. However, there was a drastic slowdown in growth in 2012, with Ghana experiencing its highest deficit. This notwithstanding, there has been an improvement in the rate of poverty, literacy rate, provision of social amenities such as clean water, electricity, access to health care through the national health insurance scheme, and so on. All these have affected the life expectancy rate of Ghana which now stands at 61 years. ${ }^{13}$ (See Figure 1 for the poverty rates in Ghana during the period under discussion.)

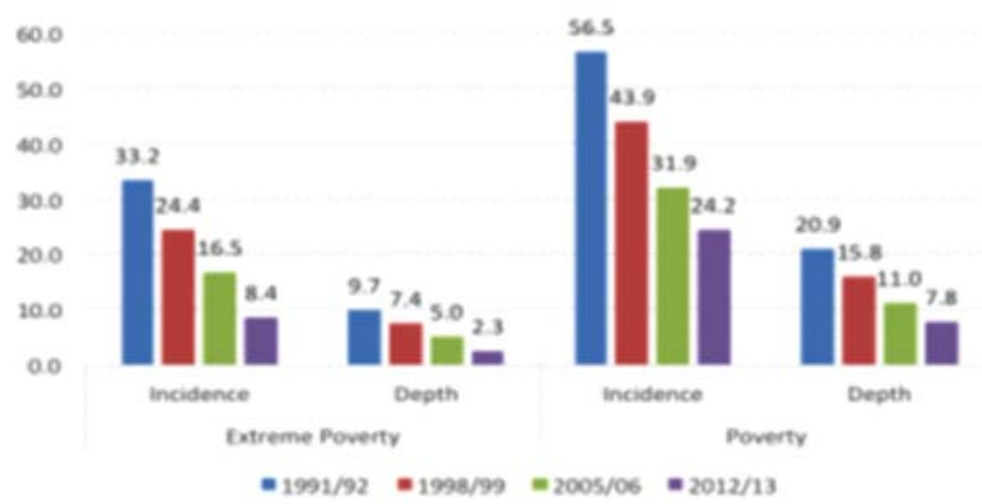

Figure 1: National Poverty Rates: 1992-2013

Source: Ghana Poverty and Inequality Report, 2016 14

Figure 1 indicates a steady decrease in poverty and extreme poverty from 1992 to 2013. This is particularly evident in the 2012/2013 figures

11 Ghana Statistical Service (2014) www.statsghana.gov.gh: http:// www.statsghana.gov.gh/docfiles/new_CPI_pdfs/CPI_Bulletin_June_2014.pdf. Accessed on 4 April 2019.

12 World Bank Group. World Development Indicators 2012 (Washington DC: World Bank Publications 2013).

13 Ibid.

14 Cooke Edgar, Sarah Hague, and Andy McKay, The Ghana Poverty and Inequality Report: Using the 6th Ghana Living Standards Survey (UNICEF 2016). 
when the country was known to have reduced extreme poverty to the barest minimum. This confirms that there has been a stable reduction in poverty over the years.

Furthermore, sectoral evaluations show that Ghana is a service economy. That is, the engine of growth in Ghana is the service sector. This includes financial intermediation, hospitality industry, information and telecommunications, and transport. We note that overreliance on the service economy and neglect of the others indirectly affects the health of the local currency. This is because there will be the overreliance on imports and fewer opportunities explored for exports. This will, in turn, affect the exchange rate and further lead to depreciation of the Ghanaian cedis. The mono-cultural economy has been a major problem for succeeding governments.

The second engine of growth is agriculture. Here, Ghana is the second largest exporter of cocoa in the world and also exports cash crops such as cashew. However, growth in agriculture has been predominantly slow for some time now even when many citizens are engaged in that sector. The reason has been that the agriculture sector is characterized by subsistence farming and the products are not directed towards export and trade. The lack of agricultural modernization and the needed implements for large-scale production, which includes capital, has been the bane of the slow growth. Indeed, those who cultivate for commercial purposes also experience enormous difficulties such as available markets, value for money and storage facilities for lean seasons. This myriad of factors affected the slow growth of the agricultural sector. We, however, add that available data from 2018 indicates a tremendous growth increase in the agricultural sector, and this has been due to government intervention programmes such as planting for food and jobs. In 2012 the total growth in agriculture was 1.3 per cent, which was an improvement over the 2011 values $(0.8 \%) .{ }^{15}$ Again, Ghana's agriculture grew by 4.65 per cent in 2014, 2.78 per cent in 2015 and 2.95 per cent in 2016. In 2017, average growth in the sector climbed to 8.36 per cent. ${ }^{16}$

15 Institute of Statistical, Social \& Economic Research (ISSER). (2013). Overview. www.isser.edu.gh: http://isser.edu.gh/images/Publication_files/SGER2014_ Overview.pdf. Accessed on 4 April 2019.

16 The Presidency, Republic of Ghana Press Briefing.. (2019). http:// presidency.gov.gh/index.php/briefing-room/news-style-2/816-8-36agricultural-growth-in-2017-a-result-of-prudent-policies-president-akufoaddo. Accessed on 4 April 2019. 
The third engine of growth is industry. We note that industrial growth has been slow over the years. Ghana's industrial growth is however concentrated in the construction and the mining sectors. The period up to 2014 did not experience any tremendous growth, but the current policies - such as one-district, one-factory - as well as certain tax breaks for start-up companies seem to have been helping the growth of the industry from 2016.

Comparatively, in 2011, Ghana recorded one of the highest GDP growths in sub-Saharan Africa at 14.4 per cent, however, growth slowed down in 2012 to 7.9 per cent and further down to 4.4 per cent $2013 .{ }^{17}$ On the one hand, the adduced reason for the high GDP growth in 2011 was that Ghana became an oil economy when it began oil export in 2010. On the other hand, the slow growth experienced from 2012 could be associated with a lack of fiscal policy management, increased government spending and international shocks on the economy. The country recorded a deficit of 12 per cent so soon after - in 2012 and almost the same in 2013. The deficit resulted from unchecked executive spending especially on elections. In 2013, the government spent 48 per cent of total revenue on public sector wages whilst public debt servicing took about 40 per cent of the total revenue. ${ }^{18}$ The increase in expenditure on public sector wages was due to the non-prudent implementation of the single-spine salary structure, which was hurriedly implemented for political gains since it was an election year. This meant that the government spent less on the provision of public goods than debt servicing. Thus, the reasons for the poor macroeconomic data remained government overspending, excessive borrowing and high public sector wage bill.

This situation was further aggravated by the continuous increase in the public debt, which stood at 53 per cent of GDP in 2013. The corollary was price hikes given that inflation in June 2014 stood at 15 per cent. ${ }^{19}$ The period also witnessed increase in utility tariffs, removal of government subsidies on petroleum and other services well as other constraints on the ordinary citizen. As far as revenue percentage was concerned, the government experienced steady increases since 2010

17 African Development Bank. African Economic Outlook. (2014).http:// www.africaneconomicoutlook.org/fileadmin/uploads/aeo/2014/PDF/EBook_African_Economic_Outlook_2014.pdf. Accessed on 30 March 2019.

18 Ibid.

19 Ghana Statistical Service (n 17). 
when revenue was at 16.8 per cent of GDP. There was a positive variance of 4 per cent in 2011 and a 1.4 per cent increase in $2012 .{ }^{20}$ All these demanded prudent monetary and fiscal discipline to bring the economy back on track. They also demanded prudent management of the petroleum revenues being accrued from the 2010 exports.

\section{FISCAL REGULATION AND TAX SYSTEM ON PETROLEUM}

There has been a constant engagement with foreign firms in the exploration of crude oil in Ghana since the 19th century. The implementation of fiscal policies to better regulate the petroleum industry was often characterized by much urgency in the early 1980s. The urgency in fiscal policy regulation of the petroleum industry lasted until 1992, a period which coincided with the military regime rule in Ghana, under the Provisional National Defence Council (PNDC). The foremost fiscal regulation of petroleum revenue is the Petroleum Income Tax Act, 1984 (PNDC Law 188). ${ }^{21}$

Basically, this law sets up the taxation system in the petroleum industry. It stipulates periods for tax deductions and what should be deducted. For instance, it establishes the payment of rentals, royalties, and other relevant deductions that ought to be made during commercial production of petroleum. This has been the guiding framework for the drafting of the Model Petroleum Agreement, 2000 and other revenue generation acts and policies as far as the production of oil is concerned. Thus, the payment of royalties, surface rentals and other taxes signed in the contracts are as specified in this law. Furthermore, the Internal Revenue Act, (2000) (Act 592) also provides the general taxation system and procedures. ${ }^{22}$

It is important to note that although the Internal Revenue Act does not directly deal with the petroleum contractors and their subcontractors, yet it regulates the taxation system of the service industries which make supplies to the subcontractors of the petroleum

20 Institute of Statistical, Social \& Economic Research (n 13).

21 Petroleum Income Tax Law. Laws. (1987). <www.ghanaoilwatch.org: http:// ghanaoilwatch.org/images/laws/petroleum_imcome_tax_pndcl_188.pdf > accessed on 4 April 2019.

22 Internal Revenue Act, 592.. Information. (2000) <www.gra.gov.gh: http:// www.gra.gov.gh/docs/info/irs_act.pdf.> accessed on 22 March 2019. 
industry. Again, employees of the companies are also entitled to pay taxes, and all these fall within the purview of the Internal Revenue Authority. Within the petroleum taxation regime, contractors are required to pay company tax. This is a tax relating to the income, investment and business transacted in Ghana. ${ }^{23}$ Filing of corporate tax returns is supposed to be done within four months of the close of the accounting year. Thus, all companies involved in the exploration operation are required to pay company tax or their returns. Again, the tax system requires that companies who hold leases in the mining sector, including petroleum exploration are to pay royalties determined by the law but at a varied rate based on the negotiations between the government and the companies.

\subsection{Ghana's Entitlements: West Cape Three Points and Deepwater Tano Contracts}

As the owner of the petroleum resources, Ghana is legally entitled to the benefits accruing from its resources. In this sense, the government, acting on behalf of the people of Ghana, receives all entitlements and due rents from oil explorations in the country. In the first instance, the government has to negotiate for percentages of entitlements with the international oil companies and reach an agreeable compromise in a manner that none of the parties will run at a loss. Having vested the management, exploration and production duties in the hands of the national oil company, in this case, the Ghana National Petroleum Corporation (GNPC), the government receives the required revenue from GNPC and undertakes development projects with them. The government also looks up to the GNPC for better-negotiated contracts to enable it to realize appreciable income from the exploration.

The GNPC, in this case, relies on the Model Petroleum Agreement (2000) to negotiate for the entitlement due government. Even though the entitlements are stated by law, the percentages still have to be negotiated. According to Article 10.1a of the model agreement, government is entitled to $12 \frac{1}{2}$ per cent in royalty on the gross production of petroleum. ${ }^{24}$ Notably, most mining agreements negotiated

23 Osei, Robert Darko, and Peter Quartey. Tax reforms in Ghana (United Nations University 2005) 2005/66.

24 Model Petroleum Agreement. Files. (2000). <www.isourcebook.org: http:// www.eisourcebook.org/cms/files/attachments/policy-legal-contractualregulatory/Ghana\%20-\%20Model\%20Petroleum\%20Agreement.pdf. > accessed on 2 April 2019. 
in Ghana range between a royalty percentage of 4 per cent to $12^{1 / 2}$ per cent. Negotiations, however, have not been more than 8 per cent of royalty. Indeed, as the second largest producer of gold in Africa, Ghana was only entitled to 3 per cent of royalty until 2011 when it was fixed at 5 per cent. ${ }^{25}$ This was highly inadequate looking at the downside effect of this activity on the environment, water bodies and the associated health effects on the inhabitants of the mining areas. These are lessons the government is expected to take into consideration when negotiating oil contracts.

Ghana is also entitled to Additional Oil Entitlements. These are profits to be accrued when there is a windfall production in oil over the normal production capacity. The percentage of profit due to government will be in accordance with the sold price at the international market and other local factors. There is also the government carried interest in the exploration, thus the government has a carried interest of 10 per cent, which is subject to an increment of 2.5 per cent if the government so wishes. ${ }^{26}$ Naturally, the GNPC, as the national oil company, holds this interest on behalf of the government. Again, income tax is paid to the government in accordance with the stipulations of the Petroleum Income Tax Law. Annual Surface rental is also charged, and the contractor is liable to pay to the government. Basically, these are the laid-down procedures through which the government receives its entitlements on petroleum exploration.

In the Deepwater Tano contract area, which covers 1,108 sq km and managed by Tullow Oil in partnership with Kosmos Energy and Sabre Oil and Gas, the government, through the GNPC, had an initial interest of 10 per cent, which also becomes the carried interest. ${ }^{27}$ It had the option of a 5 per cent additional interest in every commercial discovery and, again, government was to receive a royalty of 5 per cent on the gross production of crude oil and 4 per cent on any crude with less than $18^{\circ}$ of API. ${ }^{28}$ Additional Oil Entitlements was also payable to the government in cases of windfall production. Generally, mining

25 Bloch, Robin and George Owusu. "Linkages in Ghana's Gold mining Industry: Challenging the Enclave Thesis" (2012) 37 Resources Policy, pp. 434-442.

26 Model Petroleum Agreement. (n 27).

27 Petroleum Agreement-Deepwater Tano. Files. (2006). www.tullowoil.com: <http://www.tullowoil.com/files/pdf/petroleum_agreement_deepwater Ibid. 
companies pay an income tax of 35 per cent, thus the government was also to receive this income tax from the international oil companies. ${ }^{29}$ Although stipulated in the PNDC Law 188, this tax is subject to review and shall be applied as and when reviewed. There was also a charge for surface rentals to be paid to the state in accordance with the Petroleum Law. Per this agreement, therefore, the government was to receive between US\$30 to US\$100 per square kilometre from the exploration period to the development and production stages annually. ${ }^{30}$

This entitlement is similar to the West Cape Three Points contract area. The differences, however, are that, apart from government's 10 per cent carried interest, there can be an additional interest of 2.5 per cent. Here, again, the state is entitled to a royalty of $71 / 2$ per cent as compared to 5 per cent in the Deepwater Tano agreement. Any crude with less than $20^{\circ}$ API also attracts a royalty of 5 per cent and the surface rental in the agreement also ranges from US $\$ 20$ to US $\$ 100$ per square kilometre. ${ }^{31}$ Contractors in the petroleum industry are entitled to some tax benefits. For instance, they are not liable to export tax on any petroleum product. Again, vessels and other equipment used in their operations do not attract any import duty or taxes. Also, expatriate workers are not subject to import duties on the movement of their assets to Ghana. They are, however, required to pay income tax as citizens and other residents pay. The entitlements due government and negotiated agreements are based on the stipulated laws governing petroleum exploration and production. With these stated entitlements, Ghana has been earning a substantial amount of revenue since 2011. We noted that the total revenue accrued during the period was based on the various entitlements stated, especially the royalties, carried interest of the government, and corporate tax.

\subsection{Petroleum Revenue}

Ghana's revenue earnings from the production of oil since 2011 have formed a substantial part of government's spending. Ghana, from 2011 to the middle of 2013, was estimated to have produced a total of 77

29 Internal Revenue Act, 592 (n 25).

30 Petroleum Agreement-Deepwater Tano (n 30).

31 Petroleum Agreement - West Cape Three Points. Files. (2004). <www.tullowoil.com: http://www.tullowoil.com/files/pdf/petroleum agreement_west_cape_three_points.pdf > accessed on 22 March 2019. 
million barrels of oil with the state's share amounting to 13 million barrels. ${ }^{32}$ The revenue accruing from this indicates a substantial cash flow into the economy, enough to quicken growth. The Ministry of Finance has been charged with the responsibility of briefing Parliament periodically on the use of the petroleum revenues in accordance with the Petroleum Revenue Management Act in 2011.33

In 2011, the gross amount of produced crude oil was 24,195.895 barrels, representing a regular production of $66,290 \mathrm{bpd} .^{34}$ Added to the November and December production in 2010, Ghana lifted a total of 24,451,452 of which the State's share was 3,930,189 barrels, representing US\$444.12 million for the 2011 financial year. ${ }^{35}$ The income received in 2011 was allocated to the various funds and sectors as stipulated by law.

Table 1: Variance in Petroleum Receipts 2011

\begin{tabular}{lrrr}
\hline Item & Budget & Actual & Variance \\
\hline Royalties & $134,166,917$ & $122,941,144$ & $-11,225,773$ \\
Carried and & $297,179,343$ & $321,183,580$ & $24,004,237$ \\
$\begin{array}{l}\text { Participating } \\
\text { Interests }\end{array}$ & & & \\
Corporate Income & $402,509,557$ & & \\
Surface Rentals & 0 & 0 & $-402,509,557$ \\
Total & $833,855,817$ & $44,124,724$ & $-389,731,093$ \\
\hline
\end{tabular}

Source: Petroleum Revenue Report, 2013.

According to the Ministry of Finance, the aspect of the revenue meant for budget support was spent on five priority areas: capacity building, modernization, agriculture, oil and gas infrastructure, and

32 Ghana National Petroleum Corporation, History and Discovery. (2014) <www.gnpcghana.com: http://www.gnpcghana.com/SitePages/Content Page.aspx ItemID $=26 \&$ ItemTitle $=$ History of Exploration in Ghana $>$. accessed on 3 April 2019.

33 Petroleum Revenue Management Act. Files. (2011). <www.mofep.gov.gh: http:/ /www.mofep.gov.gh/sites/default/files/reports/Petroleum_Revenue_ Management_Act_\%202011.PDF $>$ accessed on 22 March 2019.

34 Petroleum Revenue Report. 2012 Annual Report on Petroleum Funds . (2013). <http://www.eisourcebook.org/cms/August\%202013/Ghana\%202012\%20 Report\%20on\%20Petrol\%20Revenue\%20Management.pdf > accessed on 22 March 2019.

35 Ibid. 
roads. ${ }^{36}$ In the 2012 financial year, there were increased production and revenue earnings. As indicated in Table 2, a total of 26,351,278 barrels produced with the state's share amounting to 4,931,034 yielding US\$541.62 million. ${ }^{37}$

Table 2: Petroleum Receipts Composition, 2012

\begin{tabular}{lrrr}
\hline Item & \multicolumn{3}{c}{ Dollars } \\
\cline { 2 - 4 } & Budget & Actual & Variance \\
\hline Royalties & $147,825,000$ & $150,746,644$ & $2,921,644$ \\
$\begin{array}{l}\text { Carried \& } \\
\text { Participating }\end{array}$ & $386,192,813$ & $390,428,872$ & $2,817,450$ \\
$\begin{array}{l}\text { Interest } \\
\text { Corporate Income }\end{array}$ & $239,709,791$ & & \\
Tax & & 0 & $-239,709,791$ \\
Surface rentals & 0 & & \\
& $773,727,604$ & $541,623,741$ & $-232,103,862$ \\
\hline
\end{tabular}

Source: Petroleum Revenue Report, 2013.

From this earning, government allocated US\$230.95 million to GNPC as part of its entitlement as the national oil company, used US $\$ 286.55$ million as budget support fund and saved US\$24.12 in two different funds. ${ }^{38}$ The budget allocation was to cater for the expenditure in the five priority areas as was the case in the 2011 allocation. Again, there was an increased revenue earnings in the 2013 financial year, compared to the previous two years. During this period, the total petroleum receipts amounted to US\$707.28 million, which was a positive change over the budget estimate of US\$ 581,72 million. ${ }^{39}$ This budget estimate was from January to December while the realized income was for January to September. The composition of the entitlement is indicated in Figure 2.

36 Ibid.

37 Ibid.

38 Ibid.

39 Ibid. 


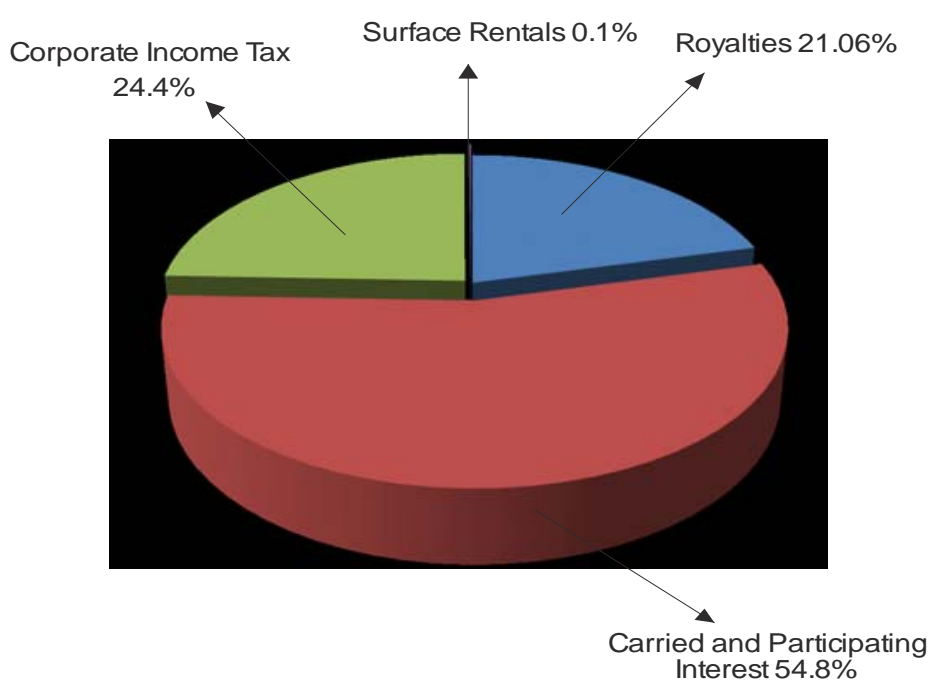

Figure 2: Composition of Revenue Entitlement in 2013

Source: (Petroleum Revenue Report, 2014) ${ }^{40}$

By law, GNPC is entitled to 40 per cent of the state's initial and carried interest, and thus received US $\$ 186.09$ million. ${ }^{41}$ The net receipts were also disbursed with 70 per cent going to budget support and 30 per cent to the Ghana Petroleum Funds. The disbursement for budgetary support was also used on the priority areas. In effect, Ghana has received a substantial amount of revenue from petroleum production, with the summary figures totalling about US $\$ 1.6$ billion since $2011 .^{42}$ This revenue had been allocated in various ways with annual budgetary allocation accounting for the greater share. What this means is that government has been injecting a greater percentage of its oil revenue into the economy. As indicated in the Petroleum Revenue Reports, the this money has been going into the priority areas designated by government. The question to ask, however, is: how has this impacted on the lives of ordinary Ghanaians. Also, to what extent can we say that the revenue has been managed well?

40 Petroleum Revenue Report. Annual Report on Petroleum Funds. (2014) < http:/ /www.mofep.gov.gh/sites/default/files/reports/2013_Annual_Petroleum_ Report.pdf $>$ accessed 3 April 2019.

41 Ibid.

42 Petroleum Revenue Report 2014 (n 43). 


\subsection{Revenue Management}

Discovering oil in commercial quantities presented a new challenge to the government. The main challenge concerns judicious management of the oil revenue to make a positive impact in the lives of ordinary people. It can be said that Ghana was unprepared for a proper husbandry of its oil earnings. There was practically no existing legal framework to determine how petroleum revenues would be disbursed and into what funds it should be allocated. Following the discovery of oil and commercial production which started in 2010, the Parliament enacted the Petroleum Revenue Management Act (Act 815), in 2011. The regulation has a key feature of establishing the various mechanisms for the petroleum revenues. Here, the law is responsible for giving the fiscal guidelines for the spending and saving of the petroleum revenues. Through these guidelines, various funds or accounts are opened into which direct allocations are to be made from the oil earnings. Act 815 also determines what percentage of these oil earnings should be allocated to the recognized funds and prescribed sectors. The guidelines in the Act aim basically at ensuring greater transparency and accountability in managing the oil revenues.

In regulating the general management of petroleum revenues, government decided to establish the Petroleum Holding Fund (PHF) to serve as the main account into which all petroleum revenues will be paid and from which all disbursement and allocations will be made. ${ }^{43}$ This means that all of Ghana's oil earnings go into this Fund with notifications sent to the Internal Revenue Authority. If the government decides to receive its entitlements in the form of crude oil, then the Internal Revenue Authority will calculate the amount of crude using the current market price and ensure payment into the Petroleum Holding Fund after the sale. ${ }^{44}$ This Fund cannot be used as a credit fund from which government can borrow money, neither can it be used as a guarantee or collateral for debts. It is a separate and independent Fund dedicated solely for the prescribed purposes. The gross receipts of the fund come from royalties, surface rentals, carried and participating interests, corporate taxes, additional oil entitlements and any other revenue due to the state through direct or interest participation in the country's oil operations.

43 Petroleum Revenue Management Act, 2011 (n 36).

44 Ibid. 
Apart from prescribing the account to which oil revenues should be paid, there is also a prescription of how the money should be allocated and disbursed. ${ }^{45}$ For example, the government established the Ghana Petroleum Funds (GPF) to deal with the savings aspect of its revenue. Hence, the Ghana Petroleum Funds receives an allocation from the Petroleum Holding Fund for incomes that are in excess of the budget benchmark. The funds are divided into the Stabilization Fund and Ghana Heritage Fund. ${ }^{46}$ The Heritage Fund is established for the purposes of long-term support for future generations. Since oil resource is non-renewable and also depletable, this Fund is supposed to help future generations by whose time the oil resource would have been depleted.

The Stabilization Fund is also established to guard against macroeconomic disruptions that could be beyond the control of the state. Ready examples of these disruptions could be the price volatility of oil on the international market, low revenue target, and so on. The Stabilization Fund will, therefore, be used to support the budget whenever the need arises. According to law, when collected revenue falls below one quarter, then withdrawals can be made from the Fund which should be less than 75 per cent of the accrued income in the Fund as well as the disbursement of 70 per cent of the net revenue from petroleum as the annual budgetary support that the government can use for development projects. ${ }^{47}$ The amount is supposed to be transferred into the Consolidated Fund before the government can make use of it.

It is important to note that after the petroleum resources are depleted, the Heritage and Stabilization Funds will be consolidated into Ghana Petroleum Wealth Fund. The Ghana Petroleum Funds are entitled to 30 per cent of the net revenue of government after disbursing that of GNPC. It is required that 30 per cent of the amount not disbursed into the national budget be allocated into the Heritage Fund and 70 per cent into the Stabilization Fund. ${ }^{48}$ We note that this is intended to make more money available for government spending especially during macroeconomic shocks. Since 2011, the government has identified four

45 Ibid.

46 Ibid.

47 Ibid.

48 Ibid. 
main concentration areas on which to spend the budgetary support allocation. ${ }^{49}$ This would mean that government has injected almost US\$1.billion dollars into these four sectors since 2011. The impact of this expenditure on the ordinary citizen is subject to critical analysis and debate.

\subsection{Transparency and Accountability}

An important step towards good governance is to hold governments accountable for their decisions, actions and inactions. ${ }^{50}$ Being held accountable is also dependent on how transparent the government is in its decision making. Oil governance, in general, and revenue management, in particular, are often shrouded in secrecy. This is the case in most oil exporting countries in Africa. Information on the use of the oil revenue and production capacity as well as the contractual agreements have mostly been unavailable for public consumption. This makes it difficult for accountability processes to be enorced, either by the people or the parliament, which has the constitutional role of instituting checks and balances.

Ghana certainly has multiple levels of checks and balances to govern its oil production and development. These include bodies such as the Public Interest and Accountability Committee (PIAC), Ghana Revenue Authority, the Ministry of Finance, Bank of Ghana, Auditor-General, and the Investment Advisory Committee (IAC). ${ }^{51}$ For instance, the PIAC has the duty to check government compliance with the management and spending of revenues from petroleum. By virtue of this mandate, the committee makes an independent assessment of government spending from petroleum revenues through consultations and the use of stipulated rules and best practices as benchmarks. The committee is made up of eleven members from diverse backgrounds, including research think-tanks, trade unions, the civil society, Ghana Journalists Association, traditional leaders, and so on.

There is also the establishment of an Investment Advisory Committee to formulate investment policies on how to manage the

49 Petroleum Revenue Report. 2013. (n 37).

50 See Damilola Olawuyi, "Increasing Relevance of Right-Based Approaches to Resource Governance in Africa: Shifting from Regional Aspiration to Local Realization" (2015) 11 (2) McGill International Journal of Sustainable Development Law and Policy, pp. 113-158.

51 Petroleum Revenue Management Act, 2011 (n 36). 
Ghana Petroleum Funds and advice the Minister of Energy accordingly. ${ }^{52}$ This committee comprises seven members who serve for a term of three years. Most importantly, the committee is tasked with submitting an annual report and analysis on the state of Ghana Petroleum Funds.

The Bank of Ghana is charged with keeping proper records of accounts on the Petroleum Holding Fund and Ghana Petroleum Funds. ${ }^{53}$ Again, these records are subject to Bank of Ghana internal audit periodically, and the Governor of the Bank is bound to submit reports to the Minister accordingly. The Auditor-General is also charged with conducting an annual external audit of the Petroleum Holding Fund. This is to synchronize the internal audit report submitted by the governor with the external audit of the Auditor-General. Additionally, the Parliament also exercises oversight checks on the activities of the Executive arm in the management and spending of the oil revenue. This is effective, especially when the Finance Minister is mandated to account for the management of the revenue annually. Through this process, the Minister is also subjected to various questions and the report goes through stages of parliamentary scrutiny before it is accepted. The internal checks and balances are necessary to avoid corruption and unguarded spending of the petroleum revenue. With these various mechanisms in place, it is expected that the development and production of oil in Ghana would positively affect the socioeconomic lives of the citizens.

\section{ASSESSMENT OF REVENUE AND FISCAL POLICIES}

Ghana has earned itself substantial revenues since it began oil export in 2011. A high percentage of this income has come from the royalty and the state's carried interest. In terms of net revenue, the state is estimated to have made around US\$1.6 billion from 2011 to September 2013. During this period, Ghana lifted about 13 million barrels of crude as its share of the total 77 million barrels produced during that period. ${ }^{54}$ Consequently, the government invested 70 per cent of its net profit into the economy. The indications suggest that by 2014 , government had spent US\$ 1 billion out of the US $\$ 1.6$ billion

52 Ibid.

53 Ibid.

54 Petroleum Revenue Report 2014 (n 43). 
realized between 2011 and 2013. This has been spent on core priority areas, namely, capacity building, modernized agriculture, roads infrastructure, and oil and gas infrastructure. The impact of this huge spending was, however, not felt by Ghanaians majority of whom have become despondent. The high expectations they had when Ghana became an oil-exporting country appears to have been dashed.

It is obvious that the government has not been committed to spending the oil receipts on the priority areas. Thus, policy proposals of government have been different from the actual practice. For instance, one the priority areas to be funded with oil revenue is agriculture. Even though as of 2014 government had spent US\$ 1 billion (62 per cent of all oil earnings between 2011 and 2013), the agricultural sector has remained untransformed. In fact, if the sector had actually enjoyed a substantial revenue injection, it would not have experienced the abysmal growth recorded from 2014 to 2016. From 4.65 per cent in 2014, the sector had negative growths of 2.78 per cent in 2015 and 2.95 per cent in 2016. This implies that government was not committed to spending on the so-called priority areas. And inability to give priority to deserving sectors of the economy is bound to result in worse social and economic indices, irrespective of the amount of money spent in the annual budgets. It will not make any difference in the lives of the people.

In the past, it might have been possible to blame government for poor planning and lack of focus on the priority areas in an economy, but this argument is no longer tenable with the adoption of Sustainable Development Goals (SDGs) as the global paradigm of development. The SDGs have conceptualized the burden of development in such a way that any country can apply itself to solving practical problems that will improve the lives of ordinary citizens if government has the political will. However, when government earmarks capacity building as a priority area, it raises many policy questions. It is expected that petroleum revenue will be injected into critical sectors of the economy; capacity building, including oil and gas, is not part of those critical sectors. Indeed, the petroleum contracts mandate the contractor to pay an annual sum of US $\$ 200,000$ to GNPC for capacity building and that this should be considered as petroleum cost. It is, therefore, unnecessary for the government to allocate part of its net profit to capacity building again.

Furthermore, Ghana is known to spend less on the provision of public goods such as quality education, health, etc, and more on 
targeted expenditure like public sector wages, and so on. ${ }^{55}$ Indeed, Ghana spent 48 per cent of its annual revenue on public sector wages in 2013, which accounted for the budget deficits of 12 per cent in 2012 and almost the same in $2013 .{ }^{56}$ Rather than this, oil revenue be invested in critical sectors of the economy so that citizens can feel its impact. The low and almost non-existent impact of the oil revenue on the economy and well-being of the citizens can be associated with the priority that government has decided to spend money on.

Even so, there seems to be no clear policy on how the government seeks to modernize a sector such as agriculture, which has served the country right from the colonial times but which still remains rudimentary. More than 80 per cent of Ghanaians living in rural areas survives on subsistence farming. Less than half of these are engaged in cash crop production and large-scale farming. This explains why the country still imports food such as rice, yellow corn and tomatoes. Thus, prioritizing agriculture is indeed a critical area which requires a clear policy direction. The lack of policy thus makes it difficult to know how to use available resources to transform agriculture.

The government needs to take urgent steps to design a policy for the modernization of agriculture to take care of both large-scale and subsistence farming. Equally important is the need to review the fiscal policy of the state. It is imperative to maintain a disciplined fiscal policy to ensure that funds are well allocated and managed. In the period under review, funds allocation and expenditure has not made any meaningful impact in the lives of the people. Any policy that does not improve people is definitely a waste.

\subsection{Saving Rate}

Oil resources are depletable; they do not last forever. This means that the rate of saving has to be commensurate with the horizon of depletion. Ghana's oil reserves are expected to last until 2030. This makes savings critical. Currently, Ghana saves only 30 per cent of the net budgeted profit for future use. Even with that, only 30 per cent of this allocation is saved for long-term use. This policy has to be reviewed because, in the extraction industry, savings ought to increase as the horizon shortens. In other words, the rate of savings has to rise as the resource

55 World Bank. Group. World Development Report. Income Data (2007).

56 African Development Bank 2014. (n 20). 
gets depleted. This will provide more income for the future generation. Because of this, it is important to develop other sectors of the economy to earn more revenue. Overdependence on natural resources, in this case, oil, will not necessarily promote development and too much reliance on it is a recipe for avoidable economic woes. Generally, Ghana needs to consider a lot of factors in its oil governance. Even though it is too early to say that resource curse is already here, it is also time for the population to feel the impact of the oil revenue. More importantly, transparent governance needs to be deepened to further promote efficient and best governance practices.

\subsection{Transparency}

Transparency has been a major problem in oil economies. The secrecy surrounding oil operations makes it easy for rent-seeking, patronage, and corruption to thrive. Many oil exporting countries in Africa have conducted their petroleum exploration and monitoring outside of the knowledge of the people they represent in government. Transparency in this sense is two-fold; internal checks and balances of the major players and monitoring institutions, and the external openness where information is open for public consumption and investigation. Effective transparency is dependent on the political regime. Again, when citizen awareness is high, they will also demand transparency and accountability from their government. Thus, transparent practices in the exploration operation are fully dependent on the political will.

As far as internal transparency measures are concerned in Ghana's oil production, there are checks and balances mechanisms. For instance, the Minister of Finance is required by law to prepare an annual petroleum revenue report before Parliament detailing out how oil revenue is spent. Again, the Auditor-General is charged with an annual audit of the Petroleum Holding Fund while the Bank of Ghana is expected to keep up-to-date records of the account and furnish the Minister in charge with periodic reports. The internal transparency mechanisms, though laudable, are also affected by unhealthy politicization and weak institutional base. For instance, GNPC as the national oil company, is sometimes accused of investing petroleum funds in non-petroleum ventures that have caused financial losses to the state. Indeed, the Parliament, which ought to exercise total oversight over the activities of the Executive, also engages in highly polarized debates. This seems an unending circus especially when the 1992 constitution mandates 
the President to appoint at least 50 per cent of ministers from Parliament.

In terms of external transparency, there is more to be achieved, especially when Article 16 clause 4 of the petroleum contracts states that every information and data concerning the operation ought to be kept confidential and can be disclosed only when it is approved by GNPC. ${ }^{57}$ This explains why the government of Ghana refused to publish the contract agreements it entered into with transnational oil companies on petroleum operations. With the establishment of the Extractive Industries Transparency Initiative (EITI) in Ghana, the country seems to be moving towards a more transparent operation.

\section{CONCLUSION}

Ghana has instituted regulations and mechanisms to ensure equitable distribution of income realized from the oil operation. However, the avoidance of resource curse by a country depends on the management and use of government revenue realized from the exploration of its natural resource. Countries such as Nigeria, Angola, Equatorial Guinea, and so on, which experience massive economic and sometimes security problems in their oil operations also grapple with the debilitating factor of revenue mismanagement. Experience has shown that, having these operational mechanisms, legislation and checks and balances procedures are necessary but not sufficient conditions for increasing sustainable development. Indeed, all oil exporting countries do have regulatory frameworks; the problem is the extent to which the respective governments spend the money in the critical areas of the economy for accelerated growth. The addition to that is how strong public institutions are at enforcing the regulations. Again, there is the problem of government's commitment to implementing its own avowed policies to quicken development. These were the considerations that led to this assessment of the impact Ghana's growing oil revenue on the lives of the people.

Notably, the lack of government prioritization and policy direction will surely lead to a non-realization of a positive impact of the rising revenue on living standards. Furthermore, countries that export oil, especially developing and economically weak ones, are also vulnerable to the volatility of oil prices. Since the price of oil rises and falls

57 Model Petroleum Agreement. (n 27). 
intermittently, it affects both budget projections and fiscal policy implementation. This implies that the government should take pragmatic steps to overcome such challenges. The government has to devise a means of implementing good fiscal policies to ensure better management of the oil proceeds by prioritizing traditional sectors such as agriculture and industry to boost its export potentials and make life easier for its people. 